Int. J. Dev. Biol. 52: 607-613 (2008)

doi: $10.1387 / \mathrm{ijdb} .072554 \mathrm{bn}$

\title{
Ion channels that control fertility in mammalian spermatozoa
}

\author{
BETSY NAVARRO, YURIY KIRICHOK\#, JEAN-JU CHUNG and DAVID E. CLAPHAM* \\ Howard Hughes Medical Institute, Department of Cardiology, Children's Hospital, Department of Neurobiology, Harvard Medical School, \\ Enders 1309, Children's Hospital Boston, 320 Longwood Avenue, Boston, MA, USA.
}

\begin{abstract}
Whole-cell voltage clamp of mammalian spermatozoa was first achieved in 2006 . This technical advance, combined with genetic deletion strategies, makes unambiguous identification of sperm ion channel currents possible. This review summarizes the ion channel currents that have been directly measured in mammalian sperm, and their physiological roles in fertilization. The predominant currents are a $\mathrm{Ca}^{2+}$-selective current requiring expression of the $4 \mathrm{mCatSper}$ genes, and a rectifying $\mathrm{K}^{+}$current with properties most similar to $\mathrm{mSlo3}$. Intracellular alkalinization activates both channels and induces hyperactivated motility.
\end{abstract}

KEY WORDS: CatSper, KSper, Ca ${ }^{2+}$, hyperactivated sperm motility, patch clamp, sperm, $C a^{2+}$ channel

\section{Introduction}

Mature mammalian spermatozoa are quiescent in the male reproductive tract. Upon ejaculation, they become motile. As they move through the female reproductive tract, they become competent to fertilize the egg. During this period, called capacitation, spermatozoa begin to move progressively, develop hyperactive motility, and their acrosomes can react (Yanagimachi, 1994). Capacitation requires changes in intracellular $\mathrm{pH}\left([\mathrm{pH}]_{j}\right)$, concentrations of $\mathrm{Ca}^{2+}$ $\left(\left[\mathrm{Ca}^{2+}\right]_{\mathrm{i}}\right)$ and cAMP. The molecular mechanisms responsible for these changes are an active area of research.

$\left[\mathrm{Ca}^{2+}\right]_{\mathrm{i}}$ is increased either as $\mathrm{Ca}^{2+}$ enters the cytoplasm through plasma membrane ion channels, or as $\mathrm{Ca}^{2+}$ is released from intracellular stores. Many $\mathrm{Ca}^{2+}$-permeable channels have been proposed to participate in sperm cell processes (Darszon et al., 2006), including classical voltage-gated $\mathrm{Ca}^{2+}-\left(\mathrm{Ca}_{\mathrm{V}}\right)$, transient receptor potential(TRP), and cyclic nucleotide-gated- (CNG) channels. This review summarizes two particular ion currents in sperm cells, $\mathrm{Ca}^{2+}$ current $\left(\mathrm{I}_{\text {CatSper }}\right)$ and $\mathrm{K}^{+}$current in spermatozoa $\left(\mathrm{I}_{\mathrm{KSper}}\right)$ that have been directly measured with the recently developed whole-sperm cell patch clamp (Kirichok et al., 2006; Navarro et al., 2007).

\section{CatSpers1-4}

The first member of the CatSper (Cation channel of sperm) family, CatSper1 was detected during searches for sequence homology to the voltage-gated $\mathrm{Ca}^{2+}$-selective channels $\left(\mathrm{Ca}_{\mathrm{v}}{ }^{1-3}\right)$ (Ren etal., 2001). The mouse CatSper1gene is located on mouse chromosome 19 and consists of 12 exons with an open reading frame (ORF) encoding a 686 amino acid protein. CatSper2 was discovered as a sperm cell-specific transcript using a signal peptide trapping method. Mouse chromosome 2 contains the CatSper2 gene, encoding a protein of 588 amino acids in length (Quill et al., 2001). CatSper2 has at least 3 splice variants. The last two members of the family, CatSper3 and CatSper4, were found in database searches (Jin et al., 2005, Lobley et al., 2003, Qi et al., 2007). CatSper3, on mouse chromosomes 13, encodes a 395 amino acid polypeptide, while CatSper 4, on mouse chromosome 4, encodes a 442 amino acid protein. Both CatSper3 and CatSper4 have several potential splice variants. The four CatSper proteins have relatively low sequence identity in the transmembrane regions, ranging from 16 to $22 \%$. Mouse CatSper orthologs have been found in all mammals examined (human (Fig. 1), chimpanzee, dog, and rat), in sea squirt (Ciona intestinalis), and sea urchin (Strongylocentrotus purpuratus). CatSpers have not yet been identified in fish (Fugu rubripesand Danio rerio), flies (Drosophila melanogaster), worms (Caenorhaditis elegans), or

\footnotetext{
Abbreviations used in this paper: CatSper, sperm-specific cation channel; $\mathrm{Ca}_{\mathrm{v}}$, voltage-gated calcium channel; CNG, cyclic nucleotide-gated calcium channel; ORF, open reading frame; TRP, transient receptor potential calcium channel.
}

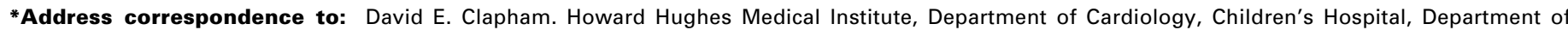

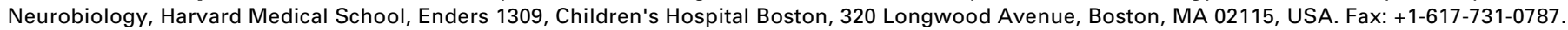
e-mail: dclapham@enders.tch.harvard.edu
}

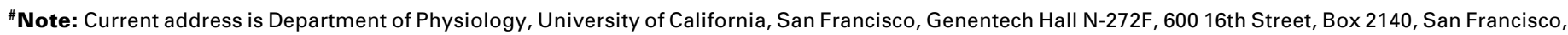
CA 94158-2140. e-mail: yuriy.kirichok@ucsf.edu

Published online: 4 July 2008

0214-6282/2008/\$35.00

(C) UBC Press

Printed in Spain 
plants (Arabidopsis thaliana).

\section{Structural domains of CatSper proteins}

The functional channel polypeptides with the closest similarity to CatSpers are the voltage-gated sodium channels $\left(\mathrm{Na}_{v} \mathrm{BP}\right)$ in bacteria and the mammalian $\mathrm{Ca}_{\mathrm{V}}$ family. The predicted topology of all 4 members of the CatSper family consists of cytoplasmic amino- and carboxyl-termini flanking 6 transmembrane (6TM)spanning segments (S1-S6; Fig. 1). Like other voltage-gated channels, these segments are arranged into 2 functionally distinct modules: the voltage sensor (S1-S4) and the pore-forming (S5-P loop-S6) domain. All known $\mathrm{Ca}_{\mathrm{V}}$ s have 4 repeats of the 6TM domain (arising from gene duplication of a single 6TM gene). $\mathrm{Ca}^{2+}$-selectivity is suggested by negatively charged amino acids in the pore consensus sequence ([T/S]x[D/E]xW). CatSpers1-4 each contains a similar conserved motif, TxDxW.

The S1-S4 segments of voltage-gated channels are called the voltage sensor domains (VSDs). The VSD contains 4 to 6 positively charged amino acids (arginine $(\mathrm{R}) /$ lysine $(\mathrm{K})$ ) spaced at helical turns (3 amino acid intervals) in the S4 segment. Voltage changes move the S4 segment, resulting in conformational changes that open and close (gate) the pore. CatSper1 and CatSper2 contain 4, while CatSper3 and CatSper4 have only 2, R/ $\mathrm{K}$ residues in the S4 segment. The relative lack of changes in S4 in CatSper3 and CatSper4 may be responsible for the reduced
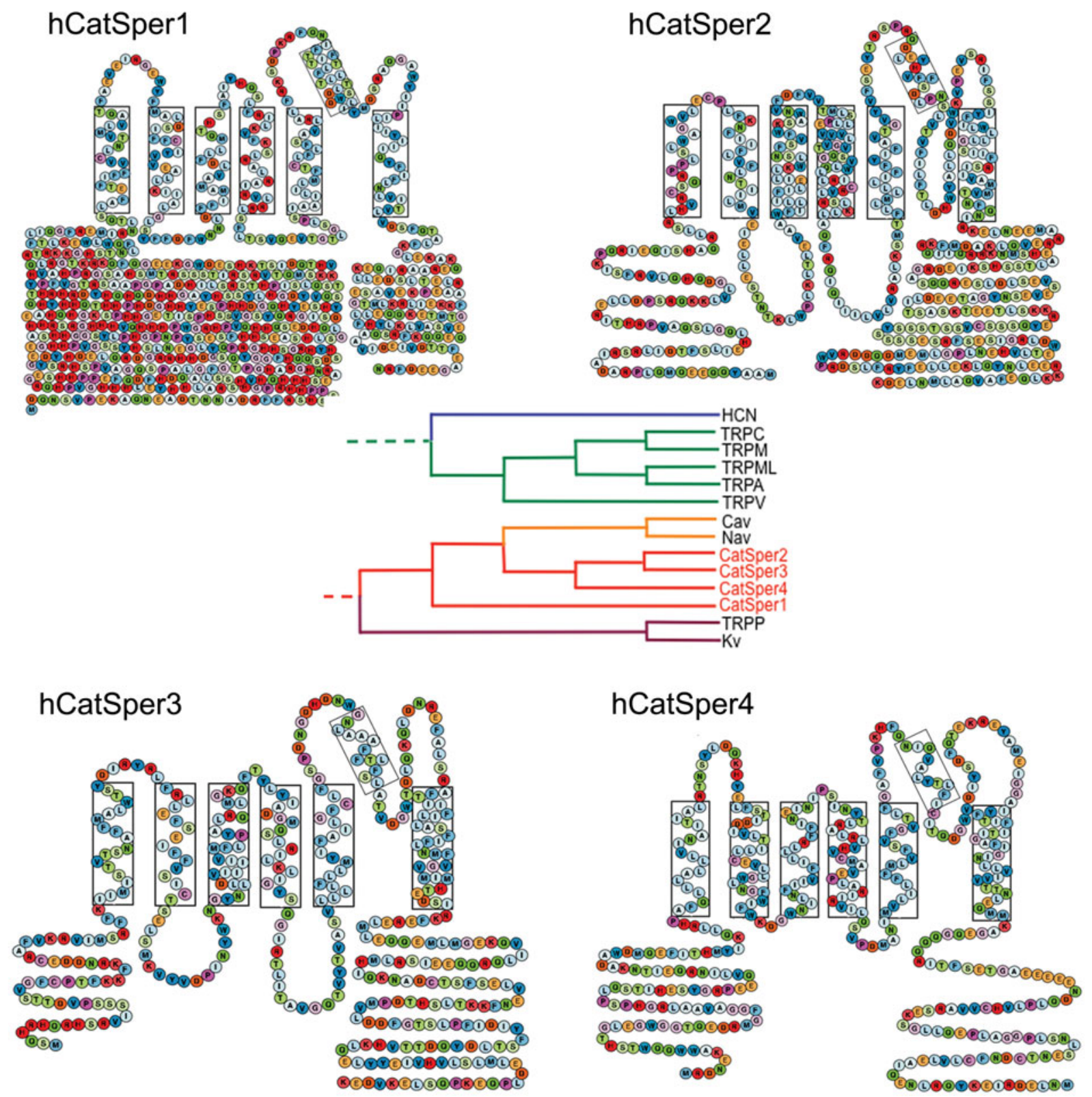

Fig. 1. Human CatSper1-4 predicted secondary topology. CatSper1-4 have 6TM with a putative voltage sensor (S1-S4) and a pore (S5-S6) domain. Phylogenetic tree (anchored to NaChBac) is shown in the center. Boxes indicate putative transmembrane segments. 
voltage dependence of the CatSper heterotetrameric channel.

The amino-termini of CatSper2, 3 and 4 are fairly well conserved, but CatSper1's amino terminus is remarkable for its abundance of histidine residues (49/250 amino acids) (Ren et al., 2001). The histidine rich amino terminus suggests that CatSper1's amino terminus might be involved in $\mathrm{pH}$ regulation of CatSper currents, although other functions are equally plausible. All four of the CatSper proteins contain a coiled-coil domain within their carboxyl-termini, suggesting that heteromultimerization involves these domains. Immunoprecipitation studies performed in CatSper2-nul/ mice provide evidence that stable expression of CatSper1 protein in sperm requires CatSper2 (Carlson et al., 2005). Similarly, studies with CatSper1, 3, and 4 null mice demonstrated that stable CatSper3 and 4 required CatSper1 expression, supporting the heteromultimerization (Fig. 2) of these subunits (Qi et al., 2007).

\section{Tissue distribution and localization of CatSpers}

Several laboratories have profiled gene expression of each member of the CatSper family by multi-tissue northern blot analysis. CatSper1, 2, 3 and 4 mRNA was detected exclusively in mouse and human testis (Jin et al., 2005, Qi et al., 2007, Quill et al., 2001, Ren et al., 2001). In situ hybridization studies of CatSper subtypes suggest that CatSpers are differentially transcribed during spermatogenesis. CatSper1 (Ren et al., 2001), CatSper3 and 4 (Jin et al., 2005, Qi et al., 2007, Schultz et al., 2003) transcripts are restricted to the late-stage germ-line cells (spermatids) in testes, while CatSper2 (Quill et al., 2001, Schultz et al., 2003) transcription begins in the early-stage of spermatogenesis (pachytene spermatocytes). Consistent with in situ hybridization studies, real time PCR demonstrated that the CatSper2 transcript was detected in the testis from P8 (postnatal day) mice, whereas transcription of CatSper1 started at P18. CatSper 3 and 4 mRNAs appeared in mouse testis at P15 (Li et al., 2007).

CatSpers 1-4 protein localization by antibody staining has proven to be difficult due to lack of specific CatSpers2-4 antibodies. When CatSper subtype null mice are used as controls, CatSpers 1-4 proteins are recognized only in testis. Within spermatozoa, CatSpers localize to the principal piece of the flagella (Jin et al., 2005, Qi et al., 2007, Quill et al., 2003, Ren et al., 2001). Genetically deleted mouse controls would be useful in testing the validity of the large number of other ion channel localization studies.

\section{CatSper $\beta$, an auxiliary subunit of the CatSper1 complex}

Transgenic mice were made in which HA-GFPCatSper was inserted on a CatSper1-nul/mice background (Li et al., 2007). This gene restored fertility in CatSper1 null mice, and the HA and GFP tags allowed for reliable protein purification and identification. Using this strategy, two testis-specific proteins were identified: a heat-shock protein, HSP702 , and a novel protein subsequently named CatSper $\beta$.
The mouse CatSper $\beta$ gene on chromosome 12, encodes an 1109 amino acid protein with its 2 transmembrane segments connected via a large extracellular ( 1000 amino acid) domain. CatSper $\beta$ homologs are present in mammals, sea squirt ( $C$. intestinalis) and sea anemone ( $N$. vectensis), and like CatSper1, are absent in $C$. elegans and $D$. melanogaster. Immunoprecipitation studies with a native sample (or testicular membrane lysate) demonstrated that CatSper $\beta$ interacts with CatSper1, and like CatSper2-4, is missing in CatSper1-nul/spermatozoa (Liu etal., 2007). CatSper $\beta$ is localized to the principal piece of the sperm flagella. Taken together, these findings suggest that CatSper $\beta$ is an auxiliary subunit of the CatSper1 complex. Functional interactions and potential regulation of the CatSper complex by CatSper $\beta$ in spermatozoa are currently being studied.

\section{CatSpers form a Ca ${ }^{2+}$-selective channel}

To examine the basic functional properties of ion channels, they must be tested in voltage clamp under varying ionic conditions. Until recently, transmembrane voltage-clamp recordings in sperm were not possible. Thus, attempts were made to express CatSper proteins in heterologous systems. Despite much effort, heterologous expression of CatSper family members (in various mammalian cell lines and Xenopus oocytes), alone or in combination, failed to yield measurable current. However, initial measurements of $\mathrm{Ca}^{2+}$ influx in sperm cells were carried out using $\mathrm{Ca}^{2+}$-sensitive fluorescent probes. cGMP (Ren et al., 2001) application or depolarization with alkaline $\mathrm{K}^{+}$solution increased $\left[\mathrm{Ca}^{2+}\right]_{\mathrm{i}}$, (Carlson et al., 2003, Xia et al., 2007). This inducible $\mathrm{Ca}^{2+}$ increase was abolished in sperm cells from CatSper1- and CatSper2-null mice, indicating that spermatozoa $\mathrm{Ca}^{2+}$ entry required CatSper proteins.

The recent development of sperm patch clamp, by accessing

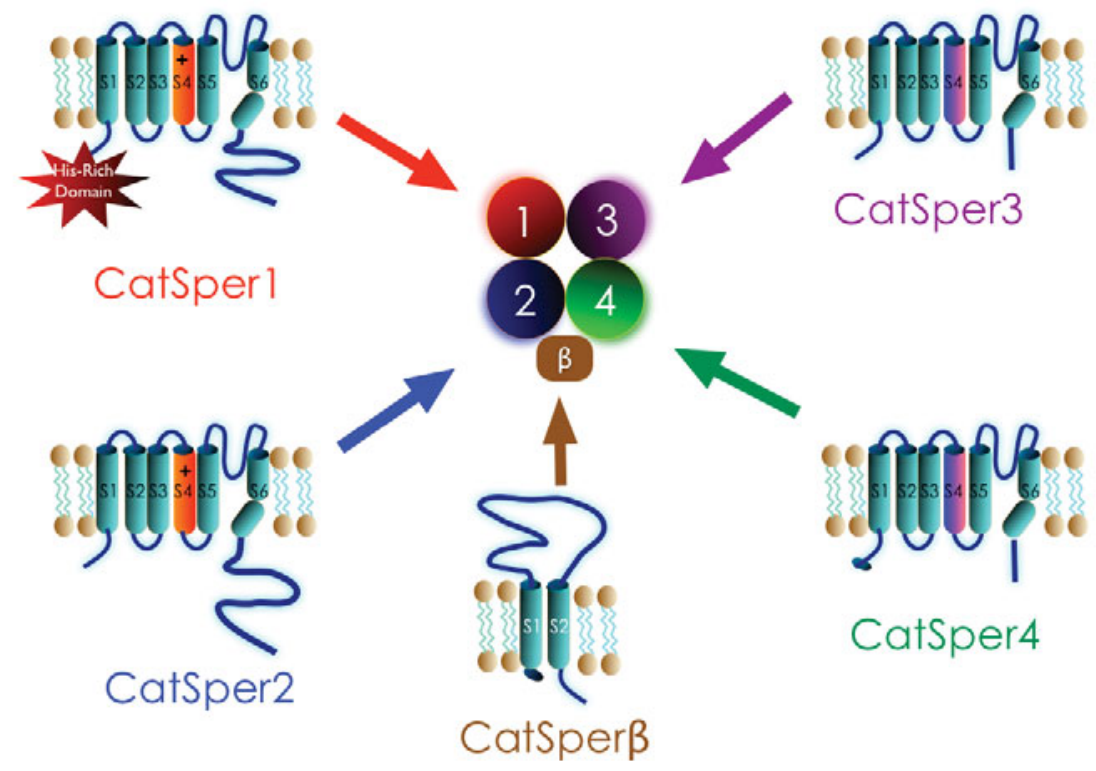

Fig. 2. Heterotetramerization of the CatSper channel. The CatSper complex is formed from CatSpers1-4 protein subunits and an auxiliary subunit. The CatSper auxiliary subunit, CatSper $\beta$, has 2 predicted transmembrane segments, separated by a large extracellular loop ( 1000 amino acids). 
the whole-spermatozoa via the cytoplasmic droplet, finally permitted characterization of CatSper currents. $\mathrm{I}_{\text {CatSper }}$ is a weakly outwardly rectifying, $\mathrm{pH}$-sensitive, $\mathrm{Ca}^{2+}$-selective current (Kirichok et al., 2006). As for many $\mathrm{Ca}^{2+}$-selective channels, barium $\left(\mathrm{Ba}^{2+}\right)$ was more permeant than $\mathrm{Ca}^{2+}$ while magnesium $\left(\mathrm{Mg}^{2+}\right)$ was impermeant. And, as for classical $\mathrm{Ca}_{\mathrm{v}}$ channels, $\mathrm{Ca}^{2+}$ itself participates in $\mathrm{Ca}^{2+}$ selectivity by binding the pore: CatSper conductance was much larger in divalent free (monovalent) solutions.

$\mathrm{I}_{\text {CatSper }}$ is weakly voltage dependent (Boltzmann slope $\sim 4$ compared to $\sim 12$ for highly voltage-dependent channels). I CatSper is, however, a very $\mathrm{pH}$-sensitive current. CatSper's $\mathrm{g}-\mathrm{V}$ curve is significantly shifted to more hyperpolarized potentials by alkaline $\mathrm{pH}$, consistent with increased CatSper current after capacitating conditions that alkalinize the intracellular environment $(\mathrm{pH} 6.8$ to the 7-8 range). An important advantage of employing spermatozoa over other cells is that, in addition to voltage clamp of intact sperm, sperm cell fragments (either the head and midpiece, or midpiece and principal piece), can be patch clamped separately (Kirichok et al., 2006, Qi et al., 2007). Using these methods, $\mathrm{I}_{\text {CatSper }}$ was specifically localized to the sperm principal piece. $\mathrm{I}_{\text {CatSper }}$ is absent in spermatozoa from CatSper1-4-nul/mice (Jin et al., 2007, Kirichok et al., 2006, Qi et al., 2007), while it remains unaltered in sperm cells from wild-type ( $w t)$ mice. In other experiments, CatSper current is unaltered in $\mathrm{Na}^{+} / \mathrm{H}^{+}$exchanger-null mice (Qi et al., 2007) when intracellular $\mathrm{pH}$ is controlled.

\section{Other $\mathrm{Ca}^{2+}$ permeant channels}

A T type $\mathrm{Ca}_{\mathrm{V}}$ current is small $(<80 \mathrm{pA})$, but detectable in spermatocytes (Escoffier etal., 2007, Ren etal., 2001, Santi etal., 1996). The T-type $\mathrm{Ca}_{\mathrm{v}}$ current is also present in CatSper1-null spermatocytes. This current is not detected in spermatocytes from $C a$ 3.2-nul/mice, and had no effect on spermatogenesis or male fertility (Escoffier et al., 2007). Within the current resolution of patch clamp $(\sim 10 \mathrm{pA})$ and $\mathrm{Ca}^{2+}$ imaging $(\sim 100 \mathrm{nM})$, no purely voltage-gated $\mathrm{Ca}^{2+}$ influx typical of $\mathrm{Ca}_{\mathrm{V}}$ channels was detected in spermatozoa from CatSpers1-4-null mice. Thus, it seems likely that classical $\mathrm{Ca}_{\mathrm{V}}$ currents $(\mathrm{CaV} 1-3, \mathrm{~T}, \mathrm{P} / \mathrm{Q}, \mathrm{N}, \mathrm{L})$ are not significant in mature spermatozoa.

\section{Male mice lacking CatSpers1-4 are infertile}

All four CatSpergenes have now been deleted separately in mice. Homologous recombination was used to delete the first putative transmembrane segment (S1) of CatSper1 (Ren et al., 2001), S1-S3 of CatSper2 (Quill et al., 2003), and the putative pore region of CatSper3 and CatSper4 (Jin et al., 2007, Qi et al., 2007). Testicular histology, epididymal sperm count, and sperm morphology was unaffected in CatSpers 1-4-nul/mice, indicating normal progression of spermatogenesis. Furthermore, there was no difference in the weight, life span, litter size, gross behavior, or mating behavior when wt and homozygous male mutant mice were compared. The striking phenotype of all CatSpers 1-4-null mice is complete male infertility; female CatSpers-nul/mice have normal fertility. To date, some form of (nonsyndromic) male human infertility has been linked to a mutation in the CatSper2 gene (Avidan et al., 2003), but other human CatSper mutations are likely to be found.
Several $\mathrm{Ca}_{\mathrm{v}}$ proteins, as well as TRPC2 and CNGA3, have been detected by antibodies in mouse spermatozoa (Carlson et al., 2003, Darszon et al., 2006). Unfortunately, none of these currents were detected in whole-sperm voltage clamp of mouse epididymal sperm cells. In addition, mice carrying null mutations for $\mathrm{Ca}_{\mathrm{v}} 1.3$ (Platzer et al., 2000), Ca 2.2 (Ino et al., 2001), $\mathrm{Ca}_{\mathrm{v}} 2.3$ (Saegusa et al., 2000), Ca 3.1 (Kim et al., 2001) and $\mathrm{Ca}_{\mathrm{v}} 3.2$ (Chen et al., 2003), TRPC2 (Stowers et al., 2002) and CNGA3 (Biel et al., 1999) have normal fertility. The $C a_{V} 1.2$ null mutant (Seisenberger et al., 2000) is embryonic lethal and $C a, 2.1$ null pups die 3-4 weeks after birth (Jun et al., 1999) before fertility can be examined. Thus, CatSper channels are the only known ion channels that specifically affect mammalian male fertility.

\section{The acrosome reaction in CatSper1-null mice}

Spermatozoa must release the acrosomal vesicle (remnant of the Golgi apparatus) contained in the head of the sperm upon contact with egg's zona pellucida. The acrosome reaction (AR) releases proteolytic enzymes from the head of the sperm cell that enable penetration of the oocyte extracellular matrix (cumulus cells and zona pellucida) (Yanagimachi, 1994). Although an increase in $\left[\mathrm{Ca}^{2+}\right]_{i}$ is required for the $\mathrm{AR}$, the source of this $\mathrm{Ca}^{2+}$ is not clear (Publicover et al., 2007). Interestingly, alkaline $\mathrm{K}^{+}$ depolarization and cell-permeable cGMP application induced the $\mathrm{AR}$ in CatSper1-nul/spermatozoa. Alkaline $\mathrm{K}^{+}$depolarization did not measurably increase $\left[\mathrm{Ca}^{2+}\right]_{\mathrm{i}}$ in these CatSper1-null sperm cells (Xia et al., 2007). These data suggest that the AR does not require $\mathrm{Ca}^{2+}$ entry via plasma membrane ion channels.

\section{Hyperactivated motility requires CatSpers 1-4}

Upon deposition in the vagina, immotile sperm acquire motility by contact with bicarbonate $\left(\mathrm{HCO}_{3}{ }^{-}\right)$. Flagellar motion is symmetrical, low amplitude, and higher frequency when sperm cells are at the entrance of female reproductive tract. In the egg's vicinity, where $\mathrm{pH}$ is $7-8$, sperm cells develop hyperactivated motility that is characterized by asymmetrical (whip-like), high amplitude, and lower frequency flagellar beating (Ho and Suarez, 2001). Hyperactivated motility, essential for penetration through egg's zona pellucida, requires elevation of $\mathrm{Ca}^{2+}$ in the sperm flagellum (Lindemann and Goltz, 1988).

In vitro fertilization (IVF) studies showed that CatSper1-and CatSper2-null spermatozoa were incapable of fertilizing intact eggs (Quill et al., 2003, Ren et al., 2001). Mutant spermatozoa were able to initiate the fertilization process only after removal of the egg's zona pellucida. Since the acrosome reaction is normal in CatSper1- and CatSper2-null sperm cells, the most likely defect was in motility or hyperactivated motility. $\mathrm{Ca}^{2+}$-independent motility was initially normal in CatSpers 1-4-nul/ spermatozoa, but mutant sperm cells failed to develop $\mathrm{Ca}^{2+}$-dependent, hyperactivated motility (Carlson et al., 2005, Carlson et al., 2003, Jin et al., 2007, Qi et al., 2007). Ca ${ }^{2+}$ entry through CatSper channels is required for sperm hyperactivated motility and enhanced $\mathrm{Ca}^{2+}$ influx induced by alkalinization leads to increased flagellar bending. This result confirms the essential role of $\mathrm{Ca}^{2+}$ ions in sperm cell motility and fertility. Interestingly, CatSper mutant spermatozoa display a gradual decrease in motility (Jin et al., 2007, Qi et al., 2007) and lower ATP levels compared to wt 


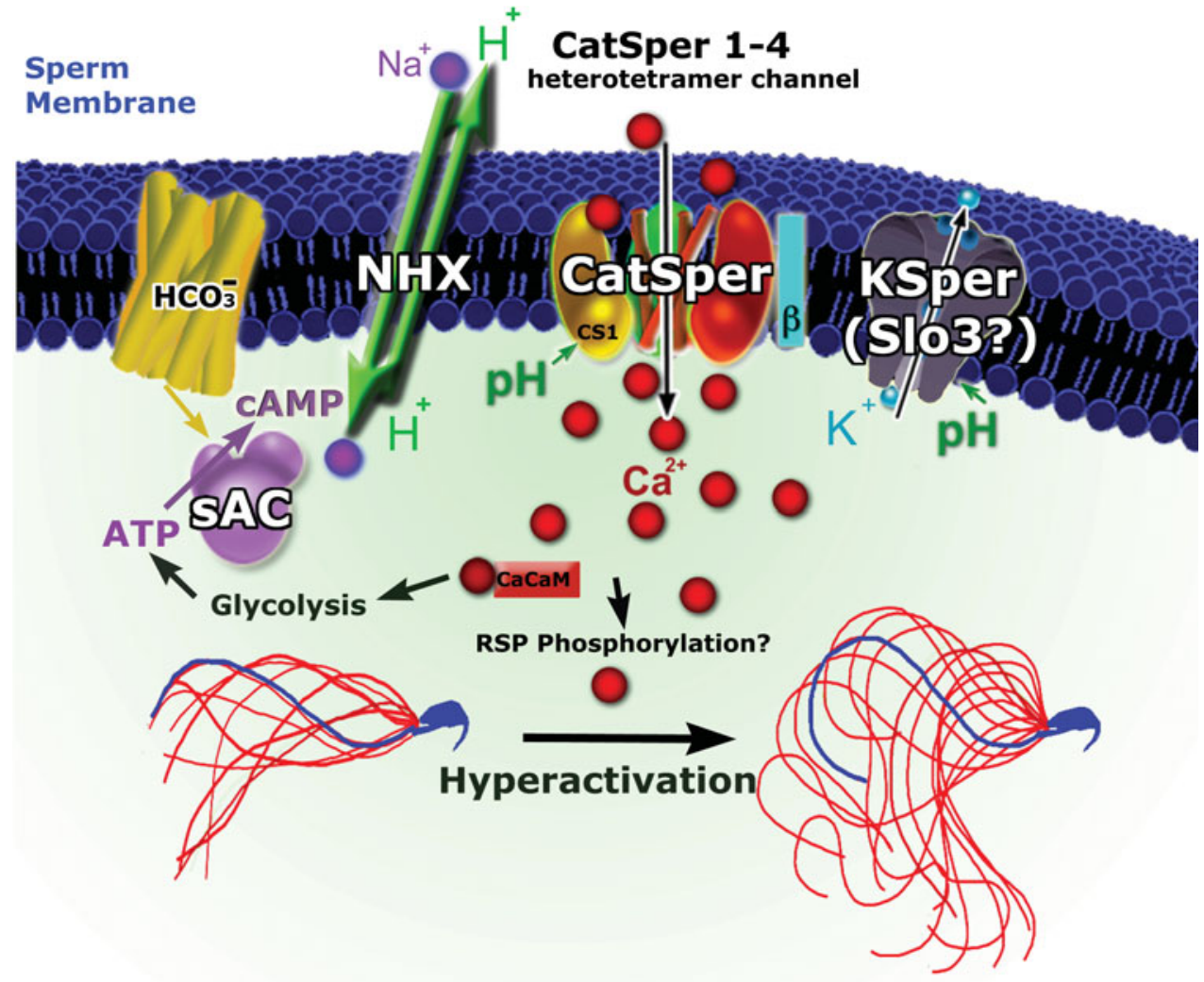

Fig. 3. Spermatozoa ion channel activation and regulation - proposed integrated model. $\mathrm{HCO}_{3}^{-}$ions enter and activate soluble adenylyl cyclase (sAC) that in turn increases cAMP synthesis. cAMP activates (direct or indirectly) the sperm specific $\mathrm{Na}^{+} / \mathrm{H}^{+}$exchange (sNHE), thereby increasing intracellular $\mathrm{pH}$. This intracellular alkalinization potently increases I CatSper and $I_{\text {KSper }}$ Alkalinization-mediated potentiation of $I_{\text {KSper }}$ hyperpolarizes the membrane potential from $\sim 0$ to $\sim-50 \mathrm{mV}$. Ca ${ }^{2+}$ entry through I Catsper induces a rise in $\left[\mathrm{Ca}^{2+}\right]_{l}$, in turn activating Calmodulin (CaCaM) and Calmodulin Kinase (CamK). These changes increase flagellar bending and enhance ATP production, thus increasing sperm endurance and hyperactivating sperm motility. $R S P$, radical spoke protein. Images of normal and hyperactivated motile sperm modified after Carlson et al., 2005. sperm cells (Xia et al., 2007), suggesting that $\mathrm{Ca}^{2+}$ influx through CatSper channels may regulate other signaling pathways such as Glyceraldehyde 3 phosphate dehydrogenase-S (GAPDS)-dependent glycolysis (Miki et al., 2004).

Thus far, we have discussed the major mammalian inward current in spermatozoa, $I_{\text {CatSper }}$. If $I_{\text {CatSper }}$ were the only active ion channel, the membrane potential would be the reversal potential for $\mathrm{Ca}^{2+}\left(\mathrm{E}_{\mathrm{ca}}\right.$; normally $\left.+150 \mathrm{mV}\right)$. To balance $\mathrm{I}_{\text {CatSper }}$, hyperpolarizing currents must also be present.

\section{$\mathrm{K}^{+}$current in spermatozoa $\left(\mathrm{I}_{\mathrm{KSper}}\right)$}

Noncapacitated murine spermatozoon resting membrane potential is -30 mV. After capacitation, sperm cell hyperpolarize to -60 mV (Arnoult et al., 1999, Zeng et al., 1995). Using voltagesensitive fluorophores, the capacitation-associated hyperpolarization was ascribed to an increase in $\mathrm{K}^{+}$permeability (Zeng et al., 1995) and block of epithelial sodium channel (Hernandez-Gonzalez et al., 2006).

In whole-sperm patch clamp, a constitutively active, weakly outwardly rectifying $\mathrm{K}^{+}$current was measured. This current $\left(\mathrm{I}_{\mathrm{KSper}}\right)$ was specifically localized to the principal piece of the sperm flagellum (Navarro et al., 2007). I KSper was reversibly blocked by quinine, EIPA [5-( $N$-ethyl- $N$-isopropyl) amiloride], mibefradil, but clofilium block was irreversible in the time scale of the recordings. Surprisingly, 4-aminopyridine (4-AP), a nonselective $\mathrm{K}_{\mathrm{V}}$ channel blocker, enhanced $I_{\mathrm{KSper}}$ and $\mathrm{I}_{\mathrm{CatSper}}$. This effect is a consequence of 4-AP's known alkalinization of the intracellular environment. Spermatozoon intracellular alkalinization, induced by $\mathrm{NH}_{4} \mathrm{Cl}$, strongly potentiated $\mathrm{I}_{\mathrm{KSper}}$. Average $\mathrm{I}_{\mathrm{KSper}}$ increased $\sim 8$ fold when $\mathrm{pH}_{\mathrm{i}}$ was elevated from 6 to 8 . Thus, $\mathrm{I}_{\mathrm{KSper}}$ is a $\mathrm{pH}$-sensitive $\mathrm{K}^{+}$ current activated in vivo by intracellular alkalinization.

Murine Slo3 (Schreiber et al., 1998) gene is the most likely candidate responsible for $\mathrm{I}_{\mathrm{KSper}}$. $\mathrm{mSlo} 3$ is testis-specific and its ion channel properties resemble those of $\mathrm{I}_{\mathrm{Ksper}}$. $\mathrm{mSlo} 3$ is not functionally expressed in mammalian cell lines, but in Xenopus oocytes produces measurable currents potentiated by intracellular alkalinization. Currently, lack of specific antibodies available prevents immunocytochemical identification and localization of mSlo3. Deletion of the S/O3 gene from the murine genome will be required to determine if $\mathrm{I}_{\mathrm{KSper}}$ is encoded by $m S / 03$.

\section{$I_{K S p e r}$ controls the sperm membrane potential}

Current clamp experiments reveal the strong $\mathrm{pH}_{\mathrm{i}}$ dependence of the sperm membrane potential. $\mathrm{NH}_{4} \mathrm{Cl}$-induced intracellular alkalinization $\left(\mathrm{pH}_{\mathrm{i}}\right.$ increased from 6 to $\left.\sim 8\right)$ hyperpolarized the resting membrane potential from $\sim 0 \mathrm{mV}$ to $\sim-54 \mathrm{mV}$ (Navarro et al., 2007). This hyperpolarization was $\mathrm{K}^{+}$-dependent and blocked reversibly by quinine, EIPA and $\mathrm{BaCl}_{2}$, and for prolonged durations by clofilium. Together with the lack of other observed currents, these data identify $\mathrm{I}_{\mathrm{KSper}}$ as the dominant hyperpolarizing conductance within the physiological range. Thus $I_{K S p e r}$ sets the spermatozoa resting membrane potential.

\section{Integrated model and conclusion}

The oviduct, where most capacitation occurs, is high in bicar- 
bonate ( 40 to $90 \mathrm{mM}$; (Maas et al., 1977, Tienthai et al., 2004)). Capacitation is defined phenomenologically as the acquisition of the sperm's ability to fertilize an egg, but includes changes in sperm membrane reorganization, an array of tyrosine phosporylation events, increases in $\left[\mathrm{Ca}^{2+}\right]_{\mathrm{i}}$ and membrane hyperpolarization (Yanagimachi, 1994). As a result, sperm cells change from progressive to hyperactivate motility and acquire the ability to acrosome react.

In vitro fertilization (IVF) procedures are possible in part because sperm capacitation can be reproduced in vitro. The essential condition for sperm cell in vitro capacitation is incubation at $37^{\circ} \mathrm{C}$ in a medium containing $\mathrm{Ca}^{2+}, 0.4 \%$ serum albumin and $20 \mathrm{mM} \mathrm{HCO}_{3}^{-}$(Visconti et al., 1999b, Yanagimachi, 1994). Serum albumin allows cholesterol efflux from the sperm plasma membrane and perhaps induces sperm membrane reorganization (Visconti etal., 1999a). Bicarbonate (Gadella and Van Gestel, 2004) has a profound effect on mammalian sperm function, but the $\mathrm{HCO}_{3}{ }^{-}$entry pathway is not known. $\mathrm{HCO}_{3}{ }^{-}$directly activates the sperm-specific soluble adenylyl cyclase (sAC; Fig. 3) (Chen et al., 2000). Activation of SAC increases cAMP levels, which in turn activates protein kinase A (PKA)-dependent phosphorylation cascades, and tyrosine phosphorylation (Visconti et al., 1995a, Visconti et al., 1995b). sAC-nul/mice are infertile, spermatozoa motility is severely impaired (Esposito et al., 2004), and they lack the typical pattern of tyrosine phosphorylation.

Activation of the sperm-specific $\mathrm{Na}^{+} / \mathrm{H}^{+}$exchanger (sNHE), has been postulated to account for sperm intracellular alkalinization. Mice lacking this gene are sterile with severely decreased sperm motility (Wang et al., 2003). sNHE protein contains a voltage sensor domain and a cyclic-nucleotide binding site, suggesting that this protein may be regulated by CAMP and/ or membrane potential. Surprisingly, sNHE-null spermatozoa are deficient in SAC, which together with co-immunoprecipitation experiments indicates that SAC forms a complex with SNHE (Wang et al., 2007). It is still unknown whether cAMP directly or indirectly actives SNHE. It has not yet been technically possible to measure $\mathrm{pH}$ in the principal piece where sNHE is localized.

In summary, direct recordings of epididymal sperm cells under whole-cell voltage clamp reveals two primary currents, $I_{\mathrm{CatSper}}$ and $I_{\text {KSper }}$ Intracellular alkalinization activates these two specific sperm-ion currents. $I_{\text {CatSper }}$ is responsible for the increase in $\left[\mathrm{Ca}^{2+}\right]_{\mathrm{i}}$ during capacitation that enables hyperactivated motility. CatSpers 1-4-nul/ mice are infertile and the spermatozoa fail to develop hyperactivated motility. $\mathrm{Ca}^{2+}$ influx through CatSper channels increases flagellar bending in a $\mathrm{Ca}^{2+}$-dependent manner; perhaps (based on work in other cells, e.g. Chlamydamonas) by binding to calmodulin, activation of camodulin kinase, and phosphorylation of radial spoke protein(s) of the axoneme. Also, CatSper1-null spermatozoa have diminished intracellular ATP (Xia et al., 2007), suggesting that CatSper-specific $\mathrm{Ca}^{2+}$ entry may initiate flagellar glycolysis. However, $\mathrm{Ca}^{2+}$ also stimulates enzymes of the Kreb's cycle in mitochondria (see (Kirichok et al., 2004, Rizzuto et al., 2000)). Thus $\mathrm{Ca}^{2+}$ via $\mathrm{I}_{\text {CatSper }}$, or combined with $\mathrm{Ca}^{2+}$ from intracellular stores, is likely to be required for the sustained ATP production needed for extended motility and hyperactivation. In contrast, $I_{\text {KSper }}$ sets the sperm cell membrane potential and is responsible for the hyperpolarization associated with sperm capacitation. Currently there is no evidence for $\mathrm{Ca}_{\mathrm{V}}$, $\mathrm{Cl}^{-}$, or cyclic nucleotide-gated currents from direct voltage clamp of mammalian epididymal sperm cells. To play a role in fertilization, these currents would have to be rapidly upregulated after exit from the epididymis. We have not extensively tested for transmitter-gated channels (known or unknown, e.g. chemoattractants), or receptor tyrosine kinase and $G$ protein coupled receptor modulation of $\mathrm{I}_{\text {CatSper }}$ or $\mathrm{I}_{\mathrm{KSper}}$. These studies will be interesting avenues for the future.

\section{Acknowledgement}

This article is dedicated to our collaborator, David Garbers, who generously shared his friendship, time and knowledge.

\section{References}

ARNOULT, C., KAZAM, I.G., VISCONTI, P.E., KOPF, G.S., VILLAZ, M. and FLORMAN, H.M. (1999). Control of the low voltage-activated calcium channel of mouse sperm by egg ZP3 and by membrane hyperpolarization during capacitation. Proc Nat/ Acad Sci USA 96: 6757-62.

AVIDAN, N., TAMARY, H., DGANY, O., CATTAN, D., PARIENTE, A., THULLIEZ, M., BOROT, N., MOATI, L., BARTHELME, A., SHALMON, L. et al. (2003). CATSPER2, a human autosomal nonsyndromic male infertility gene. Eur J Hum Genet 11: 497-502.

BIEL, M., SEELIGER, M., PFEIFER, A., KOHLER, K., GERSTNER, A., LUDWIG, A., JAISSLE, G., FAUSER, S., ZRENNER, E. and HOFMANN, F. (1999). Selective loss of cone function in mice lacking the cyclic nucleotide-gated channel CNG3. Proc Natl Acad Sci USA 96: 7553-7.

CARLSON, A.E., QUILL, T.A., WESTENBROEK, R.E., SCHUH, S.M., HILLE, B. and BABCOCK, D.F. (2005). Identical phenotypes of CatSper1 and CatSper2 null sperm. J Biol Chem 280: 32238-44.

CARLSON, A.E., WESTENBROEK, R.E., QUILL, T., REN, D., CLAPHAM, D.E., HILLE, B., GARBERS, D.L. and BABCOCK, D.F. (2003). CatSper1 required for evoked $\mathrm{Ca} 2+$ entry and control of flagellar function in sperm. Proc Nat/Acad Sci USA 100: 14864-8.

CHEN, C.C., LAMPING, K.G., NUNO, D.W., BARRESI, R., PROUTY, S.J., LAVOIE, J.L., CRIBBS, L.L., ENGLAND, S.K., SIGMUND, C.D., WEISS, R.M. et al. (2003). Abnormal coronary function in mice deficient in alpha1H T-type Ca2+ channels. Science 302: 1416-8.

CHEN, Y., CANN, M.J., LITVIN, T.N., IOURGENKO, V., SINCLAIR, M.L., LEVIN, L.R. and BUCK, J. (2000). Soluble adenylyl cyclase as an evolutionarily conserved bicarbonate sensor. Science 289: 625-8.

DARSZON, A., ACEVEDO, J.J., GALINDO, B.E., HERNANDEZ-GONZALEZ, E.O., NISHIGAKI, T., TREVINO, C.L., WOOD, C. and BELTRAN, C. (2006). Sperm channel diversity and functional multiplicity. Reproduction 131: 977-88.

ESCOFFIER, J., BOISSEAU, S., SERRES, C., CHEN, C.C., KIM, D., STAMBOULIAN, S., SHIN, H.S., CAMPBELL, K.P., DE WAARD, M. and ARNOULT, C. (2007). Expression, localization and functions in acrosome reaction and sperm motility of $\mathrm{Ca}(\mathrm{V}) 3.1$ and $\mathrm{Ca}(\mathrm{V}) 3.2$ channels in sperm cells: an evaluation from $\mathrm{Ca}(\mathrm{V}) 3.1$ and $\mathrm{Ca}(\mathrm{V}) 3.2$ deficient mice. $J$ Cel/ Physio/212: 753-63.

ESPOSITO, G., JAISWAL, B.S., XIE, F., KRAJNC-FRANKEN, M.A., ROBBEN, T.J., STRIK, A.M., KUIL, C., PHILIPSEN, R.L., VAN DUIN, M., CONTI, M. et al. (2004). Mice deficient for soluble adenylyl cyclase are infertile because of a severe sperm-motility defect. Proc Nat/ Acad Sci USA 101: 2993-8.

GADELLA, B.M. and VAN GESTEL, R.A. (2004). Bicarbonate and its role in mammalian sperm function. Anim Reprod Sci82-83: 307-19.

HERNANDEZ-GONZALEZ, E.O., SOSNIK, J., EDWARDS, J., ACEVEDO, J.J., MENDOZA-LUJAMBIO, I., LOPEZ-GONZALEZ, I., DEMARCO, I., WERTHEIMER, E., DARSZON, A. and VISCONTI, P.E. (2006). Sodium and epithelial sodium channels participate in the regulation of the capacitationassociated hyperpolarization in mouse sperm. J Biol Chem 281: 5623-33.

HO, H.C. and SUAREZ, S.S. (2001). Hyperactivation of mammalian spermatozoa: function and regulation. Reproduction 122: 519-26.

INO, M., YOSHINAGA, T., WAKAMORI, M., MIYAMOTO, N., TAKAHASHI, E., SONODA, J., KAGAYA, T., OKI, T., NAGASU, T., NISHIZAWA, Y. et al. (2001). Functional disorders of the sympathetic nervous system in mice lacking the 
alpha 1B subunit (Cav 2.2) of N-type calcium channels. Proc Nat/Acad SciUSA 98: 5323-8.

JIN, J., JIN, N., ZHENG, H., RO, S., TAFOLLA, D., SANDERS, K.M. and YAN, W. (2007). Catsper3 and Catsper4 are essential for sperm hyperactivated motility and male fertility in the mouse. Biol Reprod77: 37-44.

JIN, J.L., O'DOHERTY, A.M., WANG, S., ZHENG, H., SANDERS, K.M. and YAN, W. (2005). Catsper3 and catsper4 encode two cation channel-like proteins exclusively expressed in the testis. Biol Reprod73: 1235-42.

JUN, K., PIEDRAS-RENTERIA, E.S., SMITH, S.M., WHEELER, D.B., LEE, S.B., LEE, T.G., CHIN, H., ADAMS, M.E., SCHELLER, R.H., TSIEN, R.W. et al. (1999). Ablation of P/Q-type $\mathrm{Ca}(2+)$ channel currents, altered synaptic transmission, and progressive ataxia in mice lacking the alpha(1A)-subunit. ProcNat/ Acad Sci USA 96: 15245-50.

KIM, D., SONG, I., KEUM, S., LEE, T., JEONG, M.J., KIM, S.S., MCENERY, M.W. and SHIN, H.S. (2001). Lack of the burst firing of thalamocortical relay neurons and resistance to absence seizures in mice lacking alpha(1G) T-type $\mathrm{Ca}(2+)$ channels. Neuron 31: 35-45.

KIRICHOK, Y., KRAPIVINSKY, G. and CLAPHAM, D.E. (2004). The mitochondrial calcium uniporter is a highly selective ion channel. Nature 427: 360-4.

KIRICHOK, Y., NAVARRO, B. and CLAPHAM, D.E. (2006). Whole-cell patchclamp measurements of spermatozoa reveal an alkaline-activated $\mathrm{Ca} 2+$ channel. Nature 439: 737-40.

LI, H.G., DING, X.F., LIAO, A.H., KONG, X.B. and XIONG, C.L. (2007). Expression of CatSper family transcripts in the mouse testis during post-natal development and human ejaculated spermatozoa: relationship to sperm motility. Mol Hum Reprod 13: 299-306.

LINDEMANN, C.B. and GOLTZ, J.S. (1988). Calcium regulation of flagellar curvature and swimming pattern in triton X-100-extracted rat sperm. Cell Motil Cytoskeleton 10: 420-31.

LIU, J., XIA, J., CHO, K.H., CLAPHAM, D.E. and REN, D. (2007). CatSperbeta, a novel transmembrane protein in the CatSper channel complex. $J$ Biol Chem 282: 18945-52

LOBleY, A., PIERRON, V., REYNOLDS, L., ALLEN, L. and MICHALOVICH, D. (2003). Identification of human and mouse CatSper3 and CatSper4 genes: characterisation of a common interaction domain and evidence for expression in testis. Reprod Biol Endocrinol1: 53.

MAAS, D.H., STOREY, B.T. and MASTROIANNI, L., JR. (1977). Hydrogen ion and carbon dioxide content of the oviductal fluid of the rhesus monkey (Macaca mulatta). Fertil Steril28: 981-5.

MIKI, K., QU, W., GOULDING, E.H., WILLIS, W.D., BUNCH, D.O., STRADER, L.F., PERREAULT, S.D., EDDY, E.M. and O'BRIEN, D.A. (2004). Glyceraldehyde 3phosphate dehydrogenase-S, a sperm-specific glycolytic enzyme, is required for sperm motility and male fertility. Proc Natl Acad Sci USA 101: 16501-6.

NAVARRO, B., KIRICHOK, Y. and CLAPHAM, D.E. (2007). KSper, a pH-sensitive $\mathrm{K}+$ current that controls sperm membrane potential. Proc Nat/ Acad Sci USA 104: 7688-92.

PLATZER, J., ENGEL, J., SCHROTT-FISCHER, A., STEPHAN, K., BOVA, S., CHEN, H., ZHENG, H. and STRIESSNIG, J. (2000). Congenital deafness and sinoatrial node dysfunction in mice lacking class D L-type Ca2+ channels. Cel/ 102: 89-97.

PUBLICOVER, S., HARPER, C.V. and BARRATT, C. (2007). [Ca2+]i signalling in sperm-making the most of what you've got. Nat Cell Biol9: 235-42.

QI, H., MORAN, M.M., NAVARRO, B., CHONG, J.A., KRAPIVINSKY, G., KRAPIVINSKY, L., KIRICHOK, Y., RAMSEY, I.S., QUILL, T.A. and CLAPHAM, D.E. (2007). All four CatSper ion channel proteins are required for male fertility and sperm cell hyperactivated motility. Proc Nat/ Acad Sci USA.

QUILL, T.A., REN, D., CLAPHAM, D.E. and GARBERS, D.L. (2001). A voltagegated ion channel expressed specifically in spermatozoa. Proc Nat/ Acad SCI USA 98: 12527-31.

QUILL, T.A., SUGDEN, S.A., ROSSI, K.L., DOOLITTLE, L.K., HAMMER, R.E. and
GARBERS, D.L. (2003). Hyperactivated sperm motility driven by CatSper2 is required for fertilization. Proc Natl Acad Sci USA 100: 14869-74.

REN, D., NAVARRO, B., PEREZ, G., JACKSON, A.C., HSU, S., SHI, Q., TILLY, J.L. and CLAPHAM, D.E. (2001). A sperm ion channel required for sperm motility and male fertility. Nature 413: 603-9.

RIZZUTO, R., BERNARDI, P. and POZZAN, T. (2000). Mitochondria as all-round players of the calcium game. J Physio/529 Pt 1: 37-47.

SAEGUSA, H., KURIHARA, T., ZONG, S., MINOWA, O., KAZUNO, A., HAN, W., MATSUDA, Y., YAMANAKA, H., OSANAI, M., NODA, T. et al. (2000). Altered pain responses in mice lacking alpha 1E subunit of the voltage-dependent $\mathrm{Ca2}+$ channel. Proc Nat/ Acad Sci USA 97: 6132-7.

SANTI, C.M., DARSZON, A. and HERNANDEZ-CRUZ, A. (1996). A dihydropyridinesensitive $\mathrm{T}$-type $\mathrm{Ca} 2+$ current is the main $\mathrm{Ca} 2+$ current carrier in mouse primary spermatocytes. Am J Physio/271: C1583-93.

SCHREIBER, M., WEI, A., YUAN, A., GAUT, J., SAITO, M. and SALKOFF, L. (1998). Slo3, a novel $\mathrm{pH}$-sensitive $\mathrm{K}+$ channel from mammalian spermatocytes. $\checkmark$ Biol Chem 273: 3509-16.

SCHULTZ, N., HAMRA, F.K. and GARBERS, D.L. (2003). A multitude of genes expressed solely in meiotic or postmeiotic spermatogenic cells offers a myriad of contraceptive targets. Proc Natl Acad Sci USA 100: 12201-6.

SEISENBERGER, C., SPECHT, V., WELling, A., PLATZER, J., PFEIFER, A., KUHBANDNER, S., STRIESSNIG, J., KLUGBAUER, N., FEIL, R. and HOFMANN, F. (2000). Functional embryonic cardiomyocytes after disruption of the L-type alpha1C (Cav1.2) calcium channel gene in the mouse. J Biol Chem 275: 39193-9.

STOWERS, L., HOLY, T.E., MEISTER, M., DULAC, C. and KOENTGES, G. (2002). Loss of sex discrimination and male-male aggression in mice deficient for TRP2. Science 295: 1493-500.

TIENTHAI, P., JOHANNISSON, A. and RODRIGUEZ-MARTINEZ, H. (2004). Sperm capacitation in the porcine oviduct. Anim Reprod Sci80: 131-46.

VISCONTI, P.E., BAILEY, J.L., MOORE, G.D., PAN, D., OLDS-CLARKE, P. and KOPF, G.S. (1995a). Capacitation of mouse spermatozoa. I. Correlation between the capacitation state and protein tyrosine phosphorylation. Development 121: 1129-37.

VISCONTI, P.E., MOORE, G.D., BAILEY, J.L., LECLERC, P., CONNORS, S.A., PAN, D., OLDS-CLARKE, P. and KOPF, G.S. (1995b). Capacitation of mouse spermatozoa. II. Protein tyrosine phosphorylation and capacitation are regulated by a cAMP-dependent pathway. Development 121: 1139-50.

VISCONTI, P.E., NING, X., FORNES, M.W., ALVAREZ, J.G., STEIN, P., CONNORS, S.A. and KOPF, G.S. (1999a). Cholesterol efflux-mediated signal transduction in mammalian sperm: cholesterol release signals an increase in protein tyrosine phosphorylation during mouse sperm capacitation. Dev Bio/214: 429-43.

VISCONTI, P.E., STEWART-SAVAGE, J., BLASCO, A., BATTAGLIA, L., MIRANDA, P., KOPF, G.S. and TEZON, J.G. (1999b). Roles of bicarbonate, cAMP, and protein tyrosine phosphorylation on capacitation and the spontaneous acrosome reaction of hamster sperm. Biol Reprod 61: 76-84.

WANG, D., HU, J., BOBULESCU, I.A., QUILL, T.A., MCLEROY, P., MOE, O.W. and GARBERS, D.L. (2007). A sperm-specific $\mathrm{Na}+/ \mathrm{H}+$ exchanger (sNHE) is critical for expression and in vivo bicarbonate regulation of the soluble adenylyl cyclase (sAC). Proc Natl Acad Sci USA 104: 9325-30.

WANG, D., KING, S.M., QUILL, T.A., DOOLITTLE, L.K. and GARBERS, D.L. (2003). A new sperm-specific $\mathrm{Na}+/ \mathrm{H}+$ exchanger required for sperm motility and fertility. Nat Cel/ Bio/5: 1117-22.

XIA, J., REIGADA, D., MITCHELL, C.H. and REN, D. (2007). CATSPER channelmediated $\mathrm{Ca} 2+$ entry into mouse sperm triggers a tail-to-head propagation. Biol Reprod 77: 551-9.

YANAGIMACHI, R. (1994). The Physiology of Reproduction New York.

ZENG, Y., CLARK, E.N. and FLORMAN, H.M. (1995). Sperm membrane potential: hyperpolarization during capacitation regulates zona pellucida-dependent acrosomal secretion. Dev Biol171: 554-63. 


\section{Related, previously published Int. J. Dev. Biol. articles}

See our recent Special Issue Developmental Biology in Poland edited by Tarkowski, Maleszewski and Kloc at: http://www.ijdb.ehu.es/web/contents.php?vol=52\&issue=2-3

See our recent Special Issue Ear Development edited by Fernando Giraldez and Bernd Fritzsch at: http://www.ijdb.ehu.es/web/contents.php?vol=51\&issue=6-7

The role of ion fluxes in polarized cell growth and morphogenesis: the pollen tube as an experimental paradigm Erwan Michard, Filipa Alves and José A. Feijó

Int. J. Dev. Biol. (2008) 52: doi: 10.1387/ijdb.072296em

The dynamics of calcium oscillations that activate mammalian eggs

Karl Swann and Yuansong Yu

Int. J. Dev. Biol. (2008) 52: 585-594

Regionalized calcium signaling in zebrafish fertilization

Dipika Sharma and William H. Kinsey

Int. J. Dev. Biol. (2008) 52: 561-570

Defective calcium release during in vitro fertilization of maturing oocytes of $L T / S v$ mice Karolina Archacka, Anna Ajduk, Pawel Pomorski, Katarzyna Szczepanska, Marek Maleszewski and Maria A. Ciemerych Int. J. Dev. Biol. (2008) 52: doi: 10.1387/ijdb.072397ka

Molecular evolution of the vertebrate mechanosensory cell and ear Bernd Fritzsch, Kirk W. Beisel, Sarah Pauley and Garrett Soukup

Int. J. Dev. Biol. (2007) 51: 663-678

Shaping the mammalian auditory sensory organ by the planar cell polarity pathway Michael Kelly and Ping Chen Int. J. Dev. Biol. (2007) 51: 535-547

Biophysical regulation during cardiac development and application to tissue engineering

Sharon Gerecht-Nir, Milica Radisic, Hyoungshin Park, Christopher Cannizzaro, Jan Boublik, Robert Langer and Gordana Vunjak-Novakovic

Int. J. Dev. Biol. (2006) 50: 233-243

Embryonic stem cells differentiate into insulin-producing cells without selection of nestin-expressing cells

Przemyslaw Blyszczuk, Christian Asbrand, Aldo Rozzo, Gabriela Kania, Luc St-Onge, Marjan Rupnik and Anna M. Wobus

Int. J. Dev. Biol. (2004) 48: 1095-1104

The choice between epidermal and neural fate: a matter of calcium.

Marc Moreau and Catherine Leclerc

Int. J. Dev. Biol. (2004) 48: 75-84

Ca2+released via IP3 receptors is required for furrow deepening during cytokinesis in zebrafish embryos.

Karen W Lee, Sarah E Webb and Andrew L Miller

Int. J. Dev. Biol. (2003) 47: 411-421

Tissue-specific distribution and variation of the channel-forming protein ductin during development of Drosophila melanogaster.

$\mathrm{J}$ Bohrmann and A Bonafede

Int. J. Dev. Biol. (2000) 44: 883-890

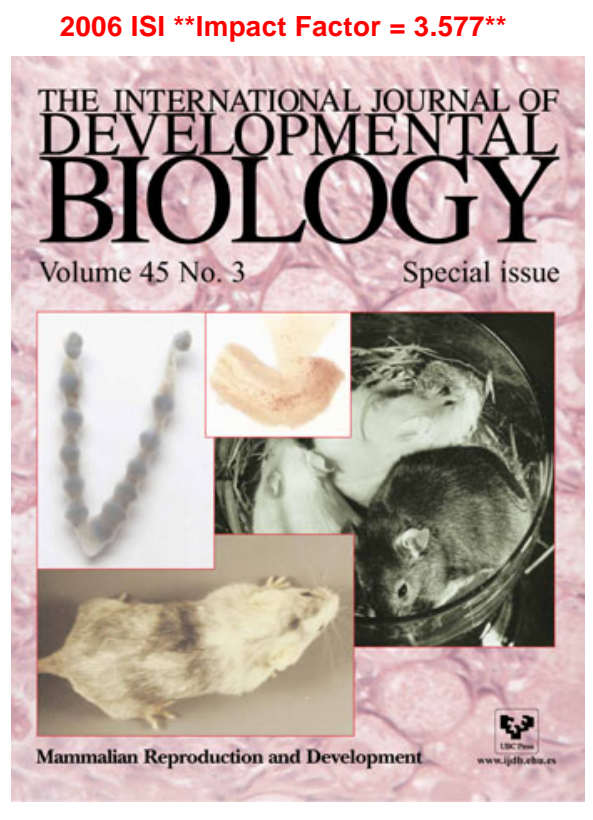

